\title{
Gabriel Podoski w opinii okolicznościowej literatury politycznej
}

Katarzyna Sałkiewicz 


\section{KATARZYNA SAŁKIEWICZ}

\section{Gabriel Podoski}

\section{w opinii okolicznościowej literatury politycznej}

$\mathrm{G}$

abriel Podoski, prymas Polski w latach 1767-1777, zyskał popularność w literaturze w latach 1767-1773, tj. od czasów konfederacji radomskiej aż do swojego wyjazdu do Gdańska. $Z$ tego okresu pochodzą utwory inspirowane prowadzoną przez niego polityką, zachowaniem, życiem osobistym, poświęcone mu w całości, jak Perekińczyk', Rozmowa księcia prymasa Podoskiego z księdzem Przedwojewskim biskupem ekskapucynem 1769 Anno ${ }^{2}$ czy Portret Jaśnie Oświeconego Księcia Podoskiego prymasa Korony Polskiej i Wielkiego Księcia Litewskiego w sierpniu 1770 r. w Warszawie odmalowany ${ }^{3}$, we fragmentach, jak Cnota Uciemiężona, wolność obarczona ${ }^{4}$ bądź też zawierające aluzje pod jego adresem. Ich autorzy oceniają go najczęściej negatywnie. Jest czarną postacią literatury barskiej, niewątpliwie najbardziej, obok króla (nb. swego wroga politycznego), znienawidzoną. Fakt ten nasuwa pytanie, skąd w świadomości ludzi uważających "wiarę" za najwyższą wartość, podejmujących walkę w jej obronie, żarliwych, a nawet fanatycznych katolików, taka niechęć do głowy kościoła w Polsce. Niechęć, której doświadczał nie on jeden spośród przedstawicieli ówczesnego episkopatu. (Przykładem m.in. Zdanie o biskupach ${ }^{5}$ i $A d-$ dytament wyroków nad biskupami $5.10 .1767^{6}$.) Jeśli zwrócimy uwagę na sytuację duchowieństwa polskiego w omawianym okresie, okaże się, że postawa Podoskiego, która stała się przyczyną negatywnej o nim opinii (nie tylko wśród barzan, ale i stronników królewskich), nie była jednostkowa ani odosobniona, choć może mniej ostentacyjnie obnoszona.

${ }^{1}$ M.in. w zbiorach Ossolińskich; rkpsy 3212, 423.

${ }^{2}$ M.in. w zbiorach Czartoryskich; rkpsy 830 IV, 865 IV.

${ }^{3}$ M.in. w zbiorach Ossolińskich; rkpsy 3042, BUW 3 k. $141 \mathrm{~V}-143 \mathrm{~V}$ (po 1945 r.).

${ }^{4}$ M.in. W zbiorach akcesyjnych BN 7068/2, rkpsy Ossolińskich 5203, 1194.

5 Druk w: Literatura barska, opr. Janusz Maciejewski, BN, S. I, nr 108, Wrocław 1976 , s. 53-57.

${ }^{6}$ Ibid., s. 57-64. 
W Rzeczypospolitej sprzed rozbiorów kościół stanowił potęge prawie zupełnie niezależną od słabego państwa, ale też pozostawał z nim w ścisłym związku. Godności biskupie należały głównie do rodzin magnackich. Biskupi zaś mieli przywilej zasiadania $w$ senacie, stale też piastowali funkcje kanclerzy lub podkanclerzych. Nic dziwnego, że Rosja, chcąc podporządkować sobie Polskę, starała się uzależnić od siebie przede wszystkim episkopat polski. Biskupi, których nie udało się kupić, byli terroryzowani. Dzięki protekcji rosyjskiej, jak podaje Konopczyński ${ }^{7}$, awansowali: Młodziejowski $i^{8}$ na biskupstwo poznańskie i kanclerstwo koronne, Massalski ${ }^{9}$ na biskupstwo wileńskie, Ostrowski ${ }^{10}$ na biskupstwo kujawskie, Giedroyć ${ }^{11}$ na biskupstwo inflanckie, Podoski ${ }^{12}$ na prymasa. Wedlug W. Korzona ${ }^{13}$, Łubieński ${ }^{14}$, poprzednik Podoskiego, przyjął od Keyserlinga ${ }^{15}$ wysoką gratyfikację ( $w$ ratach) podczas bezkrólewia i utorował drogę gwarancji rosyjs$k^{k i e j}{ }^{16}$. Ostrowski, będąc jeszcze biskupem kujawskim, miał podpisać $w$ towarzystwie kilku dygnitarzy żądanie skierowane do Repnina ${ }^{17}$, by wywiózł Sołtyka ${ }^{18}$, Załuskiego i Rzewuskich ${ }^{19}$. W latach $1773-1775$ pobierał rocznie

${ }^{7}$ W. Konopczyński, Konfederacja barska. Warszawa 1936-1938, t. I, s. 5.

8 Jędrzej Stanisław Kostka Młodziejowski (1716-1780), protegowany tubieńskiego, w 1764 r. otrzymuje podkanclerstwo koronne, w 1766 r. biskupstwo przemyskie. Po złożeniu pieczęci przez Andrzeja Zamoyskiego (1767), zostaje kanclerzem wielkim koronnym.

${ }^{9}$ Ignacy Jakub Massalski (1729-1794), syn Michała, hetmana wielkiego litewskiego. Od 1762 r. biskup wileński. Związany politycznie z obozem królewskim. Później ,jurgieltnik" rosyjski i targowiczanin, jako zdrajca powieszony przez lud warszawski w 1794 r.

${ }_{10}$ Antoni Kazimierz Ostrowski (1713-1784), od 1752 r. biskup inflancki, od 1762 r. - kujawski. Po śmierci Podoskiego został prymasem.

"Jan Stefan Giedroyć (zm. 1801), od 1764 r. biskup inflancki, związany ze Stanisławem Augustem.

${ }_{12}$ Gabriel Jan Podoski (1719-1777), stronnik saski, przeciwnik Familii i Stanisława Augusta. Po elekcji stolnika litewskiego związał się $z$ ambasadą rosyjską $i$ pobierał regularny ,.jurgielt". Po śmierci Łubieńskiego (1767), prymas Polski. Biografia w opracowaniu Emanuela Roztworowskiego znajduje się w Polskim Slowniku Biograficznym.

${ }^{13}$ W. Korzon, Wewnętrzne dzieje Polski za Stanisława Augusta. Warszawa 1882-1886, t. I, s. $255-261$.

14 Wladyslaw Aleksander tubieński (1703-1767), od 1759 r. arcybiskup gnieźnieński i prymas Polski.

${ }^{15}$ Herman Karol Keyserling (1797-1801), dyplomata rosyjski. Po zgonie Augusta III (1763), przyjechał do Polski, by popierać wybór Stanislawa Augusta.

${ }^{16}$ Jednym z glównych aktów zjazdu konfederackiego w Radomiu była prośba do Katarzyny II o gwarancję i pozostawienie wojsk rosyjskich $w$ Polsce.

${ }^{17}$ Nikolaj Repnin, książę (1734-1801), general i dyplomata rosyjski. W latach 1764-1769 ambasador $w$ Warszawie, inicjator konfederacji radomskiej $(23.06 .1767$ r.). Kazał porwać i wywieźć w gląb Rosji czterech opozycyjnych senatorów (w nocy z 13/14.10.1767 r.). Narzucił Polsce traktat gwarancyjny, uzależniający ją calkowicie od Rosji (por. przyp. 16).

${ }^{18}$ Kajetan Soltyk (1715-1788), od 1758 r. biskup krakowski, przeciwnik Familii i Stanisława Augusta, jeden z przywódców konfederacji radomskiej.

19 Józef Jędrzej Załuski (1702-1774), od 1758 r. biskup kijowski, dzialacz kulturalny i poeta. Założył wraz z bratem Andrzejem Stanisławem bibliotekę $w$ Warszawie, pierwszą w Polsce o charakterze książnicy narodowej: 


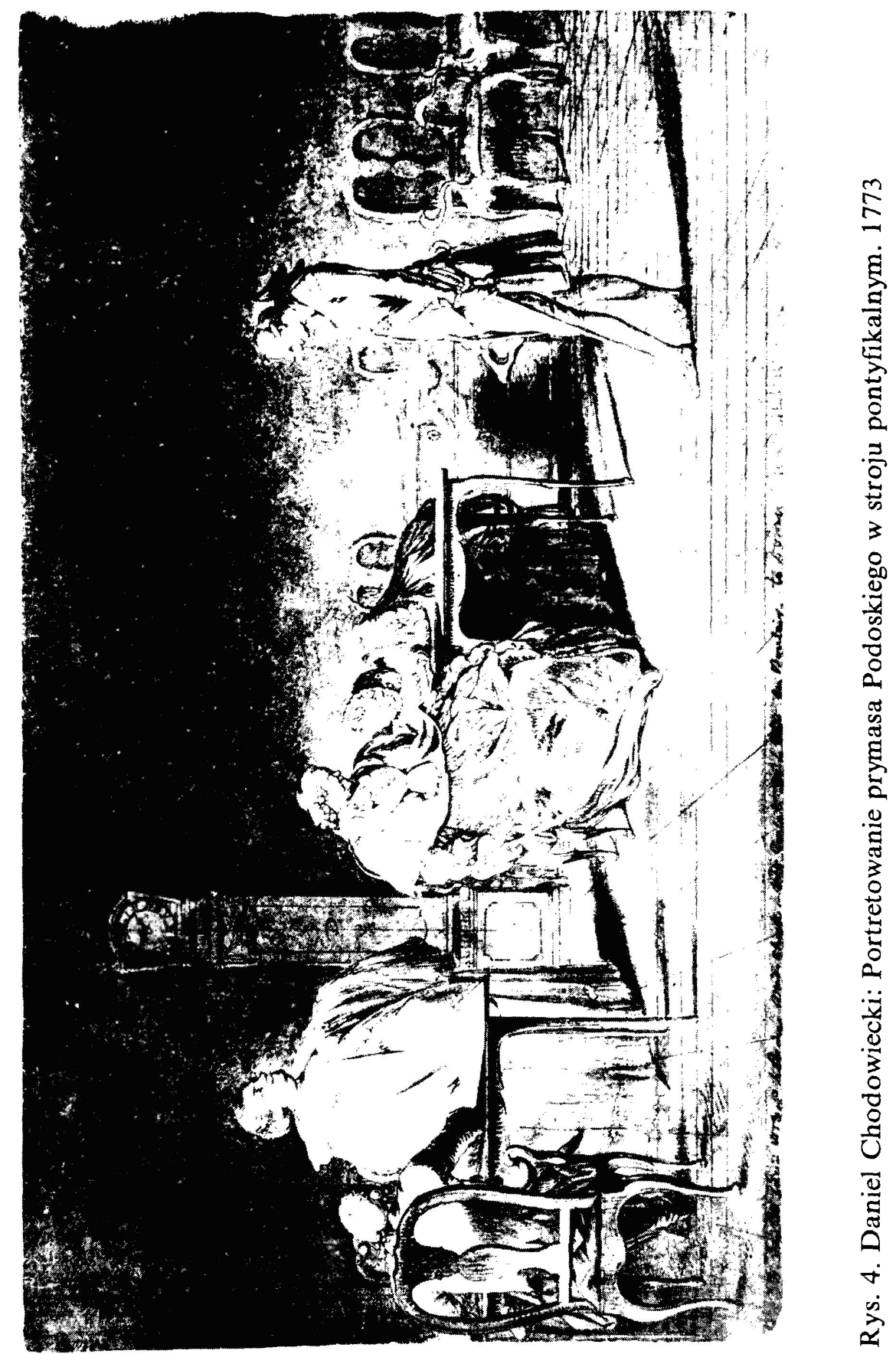


po 3000 czerwonych złotych pensji od Rosji. Kanclerz Młodziejowski, biskup poznański, za 1000 zł opowiadał Wołkońskiemu ${ }^{20}$, co dzieje się u króla na tajnych konferencjach. Massalski, biskup wileński, jeszcze w 1766 r. ściągał do swoich dóbr kwaterunek wojsk rosyjskich przeciw dysydentom. W kilka tygodni później Repnin nazwał go jednym z głównych przeciwników króla i możliwym przywódcą stronnictwa rosyjskiego. Kiedy część biskupów zaprotestowała przeciwko poczynaniom ambasadora rosyjskiego, zesłal ich w głąb Rosji (chodzi oczywiście o wspomnianych wyżej: Sołtyka i Załuskiego). Inni biskupi zamilkli wówczas. Jak określił to anonimowy autor:

Mądrych wzięto, zostali lękliwi i glupi,

Niektórzy w swym mniemaniu cicho siedzą w domu

Milczą, nie chcąc się w niczym narazić nikomu.

Pewny siedzi w Paryżu przestraszony trwogą.

Dał ekskuzy, że rady jego nie pomogą. $-^{21}$

- mowa tu o Massalskim, biskupie wileńskim. Biskupi: chełmiński - Bajer i płocki - Szeptycki² milczeli "chociaż ratunku wiara, wolność woła"23. Biskupi: żmudzki - Łopaciński ${ }^{24}$, chełmski - Turski ${ }^{25}$ oraz arcybiskup Iwowski-Sierakowski ${ }^{26}$, występujący początkowo przeciw Repninowi, umilkli po 13 października. Biskup kamieniecki - Adam Krasiński ${ }^{27}$, który w 1767 r. wyruszył do Warszawy, by wesprzeć Soltyka, zawrócił dowiedziawszy się o porwaniu senatorów.

Wacław Rzewuski (1706-1779), wojewoda krakowski i hetman polny koronny, wybitny pisarz wczesnooświeceniowy, główny oponent Repnina na Sejmie 1767 r.;

Seweryn Rzewuski (1743-1811), syn Wacława, starosta doliński, poseł na sejm 1767 r. Później, w 1774 r. hetman polny koronny. W 1792 r. stanąl na czele konfederacji targowickiej wraz z Ksawerym Branickim i Szczęsnym Potockim.

${ }^{20}$ Michał Wołkoński, następca Repnina, zorganizował 9.10 .1770 r. Radę Patriotyczna złożoną z , jurgieltników" rosyjskich na czele z prymasem Podoskim i kuchmistrzem koronnym Adamem Ponińskim.

${ }^{21}$ Rozmowa saskiego kawalera z polskim senatorem w: Literatura barska, op. cit., s. 114.

${ }^{22}$ Hieronim Antoni Szeptycki (1700-1773) od 1757 r. biskup kamieniecki, od 1759 r. - płocki;

Jędrzej Ignacy Bajer (1712-1784), od 1759 r. biskup chełmiński.

${ }^{23}$ Zdania o biskupach na sejmie teraźniejszym przy wierze i wolności obstających $1767 \mathrm{w}$ : Literatura barska, op. cit., s. 56.

24 Jan Dominik Łopaciński (1709-1778), od 1762 r. biskup żmudzki.

${ }^{25}$ Feliks Paweł Turski (1729-1800), od 1765 r. biskup chelmski.

${ }^{26}$ Waclaw Hieronim Sierakowski (1699-1784), kolejno: biskup inflancki, kamieniecki, przemyski, a od 1759 r. arcybiskup Iwowski.

${ }^{27}$ Adam Stanisław Krasiński (1714-1800), od 1759 r. biskup kamieniecki, stronnik saski; później jeden z przywódców konfederacji-barskiej,iuczestnik prac Sejmu Wielkiego. 
Wobec przedstawionych faktów uzasadniona wydaje się negatywna ocena dostojników kościoła w opinii ówczesnego społeczeństwa. To oni wszakże ponosili część odpowiedzialności za stan Rzeczypospolitej. Należy dodać, iż w drugiej połowie XVIII w., dawniej bliskie sobie pojęcia wiary, religii, Kościoła stają się coraz bardziej odległe. Duża część elity społeczeństwa używa religii już tylko na pokaz ,jako płaszczyka do wyjścia na ulice", $w$ domu zaś czci Woltera. $Z$ zachwianiem zasad religijnych do warstw wyższych wkrada się swoboda obyczajowa i libertynizm. Również wśród duchownych, zwłaszcza utytułowanych, obserwuje się postępujące zepsucie. Ostrowskiemu, biskupowi kujawskiemu, a po śmierci Podoskiego (1777) prymasowi, przypisywano posiadanie głośnego ,'haremu", zwanego później ,,prymasarnią"28. O Kajetanie Sołtyku, powszechnie przecież poważanym biskupie krakowskim, krążyły plotki na temat związków z żoną Mniszcha ${ }^{29}$ oraz Steinową-Lubomirską ${ }^{30}$. Zajmowały go obiady i pojazdy, damy, teatr, muzyka, cieplarnie. O Szeptyckim mówiono, że nie "stoi o wiarę" ${ }^{\prime 31}$. Jan Stefan Giedroyć znany był ze swej pięknej powierzchowności, dobrze widzianej wśród kobiet ${ }^{32}$. Przedmiotem satyry stał się Ignacy Krasicki jako nowomodny galant, "co mszy nigdy nie miewa, ale tylko z damami sursum corda ś́piewa", nie lubiący "mieć za wiarę trudów i zakrętów"33.

Na szczególną uwagę wśród galerii opisanych postaci zasługuje bohater tego szkicu, Gabriel Jan Podoski, prymas Polski od 17 lipca 1767 r. Na rysunkach Daniela Chodowieckiego ${ }^{34}$ z 1773 r. widać sympatycznego, korpulentnego mężczyznę $w$ różnych sytuacjach życiowych: wśród najbliższych, na spacerze, w negliżu. Wszystkie one przedstawiają jedną z najbardziej znienawidzonych postaci pojawiających się na scenie politycznej w czasach przedrozbiorowych. Określano go mianem filozofa drwiącego z wszelkiej powagi i godności, chociaż o niepospolitych zdolnościach, lekceważącego pozory, zachowującego zewnętrzność libertyna. Nie uznawał żadnych praw wiary. Bardziej zajmowało go życie doczesne, zamiłowanie do dobrej kuchni, towarzystwa i kobiet, niż starania o „koronę męczeńs-

\footnotetext{
${ }^{28}$ Por.: Literatura barska, op. cit., s. 58.

29 Jerzy August Mniszech (1715-1778), od 1742 r. marszalek nadworny koronny. Jego żona Amelia była córką Brühla, wszechwladnego ministra Augusta III. Soltyk był przyjacielem Mniszchów.

${ }^{30}$ Zob. K.M. Morawski, Stanisław August o losach Polski w: "Kwartalnik Historyczny" 1910, s. 480.

${ }^{31}$ Literatura barska, op. cit., s. 58.

${ }^{32}$ W. Korzon, op. cit., s. 255-261.

${ }^{33}$ Literatura barska, op. cit., s. 55, 63.

${ }^{34}$ Daniel Chodowiecki (1726-1801), urodzil się w Gdańsku, pochodził z polskiej rodziny i uważał się za Polaka, mimo że większość życia spędził i zmarł w Berlinie. Zdobył rozgłos jako rytownik i rysownik.
} 
ką". Mówiono, że nigdy nie zdradzał powołania kapłańskiego. Strój duchowny traktował tylko jako środek do osiągnięcia urzędów, które w tym stanie mógł zdobyć ${ }^{35}$. Jak głosiła plotka, miał jako duchowny odprawić tylko jedną mszę przy prymicjach. Nosił się po francusku i prowadził świecki tryb życia. Od młodości związany z jedną kobietą, wdową po liwerancie saskim - panią Oemichen, pozostał jej wierny aż do śmierci. Podejrzewany o próbę otrucia swego poprzednika, prymasa Łubieńskiego, o intrygi z dworem rosyjskim, które w konsekwencji doprowadziły do opłakanych dla Rzeczypospolitej skutków, nie miał szacunku u ludzi. Gardzili nim możni, bali się go i nienawidzili słabi.

Jako postać polityczna ujawnia się Podoski stosunkowo późno. Po raz pierwszy jego nazwisko pada $w$ depeszy Repnina do Panina $z$ dnia 8 kwietnia 1767 r. Z tego też roku pochodzi panegiryk Jana Kantego Śleczkowskiego Agnus Podoscianus ${ }^{36}$. Na pamiątkę wyboru i konsekracji ksiądz Cyryli Marcin Żuchowski napisał na cześć prymasa mowę pochwalną, skierowaną do króla ${ }^{37}$. Przychylnie wyrażał się o nim także Wolter w trzech broszurach zamówionych przez Katarzynę II po obradach Delegacji, stawiając go w szeregu szermierzy tolerancji. (Datowane od jesieni 1767 do lata $1768^{38}$.) Szybko jednak opinia publiczna odwróciła się od niego. Uległe wobec ambasadora rosyjskiego zachowanie przywódców konfederacji radomskiej (do których należał Podoski) sprowokowało pojawienie się w literaturze okolicznościowej już latem 1767 r. utworów, w których nie brakuje sarkazmu i kpiny wobec radomian - dotychczasowych pozytywnych bohaterów pierwszych ulotnych utworów. Znajdują się wśród nich między innymi teksty poświęcone Podoskiemu Wiersze in laudem księcia Pryma$s^{39}$. Momentem zasadniczym dla stosunku do Podoskiego polskiej opinii publicznej był początek sejmu obradującego pod węzłem konfederacji radomskiej, otwartego w październiku 1767 r., a ściślej porwanie senatorów w nocy z $13 / 14$ października. Jako pierwsze powstały utwory bezpośrednio związane z tym wydarzeniem: Perekińczyk, Cnota uciemiężona..., Zdania o biskupach na sejmie teraźniejszym przy wierze $i$ wolności obstających 1767. Addytament wyroków nad biskupami 5.10.1767 r. W tym okresie powstała prawdopodobnie Komedia Minerwa od Wenery poniżona ${ }^{40}$.

${ }^{35}$ Chodzi o referendarstwo koronne. Zanim zostal prymasem marzył o podkanclerstwie, a nawet kanclerstwie wielkim koronnym.

${ }^{36}$ Wzmianka o tym utworze w: Arcybiskupi gnieźnieńscy, prymasowie i metropolici polscy od 1000 do 1821. Warszawa 1890, t. V, s. 73.

${ }^{37}$ Arcybiskupi gnieźnieńscy..., op. cit., przyp. 3, s. 75.

${ }^{38}$ E. Roztworowski, Wolter i prymas Podoski, w: Polska w świecie, red. J. Dowiat, Warszawa 1972, s. 295-303.

${ }^{39}$ Literatura barska, op. cit., s. 39.

${ }^{40}$ Rkps Ossolineum 565 II k. 109. 
Następna w porządku chronologicznym grupa utworów pochodzi z przełomu 1767 i 1768 roku, tj. okresu obrad delegacji sejmowej, której przewodniczył Podoski. Należą tu takie wiersze, jak: Aluzja do iluminacji J.W.Ks. Mości Radziwilla Marszalka Konfederacji Generalnej z 25.11.176741, Sposób ratunku ${ }^{42}$ i Refleksje nad szubą księdzu prymasowi z Moskwy przyslaną ${ }^{43}$. Do grupy utworów powstałych w tym czasie zaliczyć trzeba także dialogi: Rozmowa saskiego kawalera z polskim senatorem ${ }^{44}$ i Odę, w której wolność z placzem rozmawia i utyskuje na czas teraźniejszy stanąwszy w senacie ${ }^{45}$. W Odzie... i Szubie... pojawiają się pierwsze, nieśmiałe jeszcze pogróżki pod adresem Podoskiego. Pierwszy z utworów obiecuje mu zemstę nieba, natomiast drugi, przez opisanie niesprawiedliwego procesu, w którym przekupni sędziowie zostają ukarani przez swego chlebodawcę, wróży taki sam koniec prymasowi.

Wśród utworów pochodzących z początku konfederacji barskiej, tj. wiosny i lata 1768 r., znajdują się Wiersze przypisane królowi, prymasowi i Repninowi $w$ Warszawie $1768 w$ maju $^{46}$ (autor radzi tu Podoskiemu siedzieć cicho, bo kiedy zwyciężą barzanie, odbierze po skórze); dialog Dyskurs ziemianina $z$ dworzaninem królewskim ${ }^{47}$ - zwracający nie po raz pierwszy uwagę na prowadzenie się głowy kościoła polskiego. W tej grupie utworów odnaleźć można także wiersze związane z procesją Bożego Ciała Opisanie nabożnej przytomności J.O.X. Gabriela Podoskiego na processyi podczas święta Bożego Ciala w Warszawie roku $1768^{48}$ oraz Processyja solenna Bożego Ciala w Warszawie roku $1768^{49}$ - oba zamieszczone w rękopisie Ignacego Ciołka Poniatowskiego ${ }^{50}$. Uroczystej procesji, w której brał udział król, senat, szlachta i tlumy wiernych, przyglądał się Prymas $z$ okien swego pałacu w towarzystwie swej kochanki, jej córki $i$ innych kobiet $z$ ich otoczenia, również protestantek. Do wydarzenia tego nawiązuje także dialog: Teraźniejsza awantura polska zawierający groźbę pod adresem arcybiskupa gnieźnieńskiego:

Mówię ja tobie, ostrzegam Baranie:

Jak cię strzyc wezmą, wełny ci nie stanie

Pożyczyć, prawda, swej Emkinia siwej-

\footnotetext{
4 "Literatura barska, op. cit., s. 52.

42 Ibid., s. 83.

${ }^{43}$ Poezja barska, opr. K. Kolbuszewski, BN, S. I., nr 108, Kraków 1928, s. 190.

44 Literatura barska, op. cit., s. 110-117.

${ }^{45}$ Ibid., s. 125-131.

46 Ibid., s. 227.

47 lbid., s. 136-215.

${ }^{49}$ M.in. w zbiorach biblioteki Archidiecezji Gnieźnieńskiej 234, s. 11-12.

49 Ibid., s. 11.

${ }^{50}$ Arcybiskupi gnieźnieńscy..., op. cit., s. 81.
} 
Ale mi wierzaj, że $i$ to są dziwy, Bo zdechnie koza, a polscy rzeźnicy Świnię zakolą i już nie zakwiczy...

Baranem nazywany jest Podoski, zaś świnią Repnin - są to aluzje do ich herbów ${ }^{51}$. Na końcu $w$ tej grupie utworów wymienić należy Muzę dysydencka i Odpowiedź na bluźnierstwa muzy dysydenckiej ${ }^{52}$, są to utwory $z$ wiosny 1768 nawiązujące jeszcze także do konfederacji radomskiej. Podoski jest w nich określany mianem „przyjaciela dysydentów".

Przedostatnią grupę utworów tworzą: Rozmowa księdza prymasa Podoskiego z księdzem Przedwojewskim biskupem ekskapucynem 1769 Anno oraz Portret polityczny J.O. Księcia Podoskiego Prymasa Korony Polskiej i Wielkiego Księcia Litewskiego w sierpniu 1770 w Warszawie odmalowany. powstałe $w$ trakcie konfederacji barskiej. Oba utwory, bogate $w$ treści polityczne i publicystyczne, zawierają opis kariery Podoskiego $i$ analizę jego postępowania. Autor Portretu... przedstawia go ponadto jako stałego adherenta Familii, najpierw jawnego, potem ukrytego, udającego jedynie przyjaciela dworu saskiego i konfederatów barskich, by przeniknąć ich plany.

Jako ostatnie utwory o Podoskim wymienić należy wiersze ze schyłku konfederacji, okresu niełaski rosyjskiej. Są to: Wiersze na ks. Podoskiego prymasa, znane także pod tytułem: Rozwód księcia prymasa Podoskiego $z$ madame Emkinią ${ }^{53}$. Pretekstem do ich powstania stało się postępowanie Salderna, który zakazał mu wyjazdu do Elbląga, dokąd wcześniej wysłał panią Oemichen. Wzmianki o Podoskim odnajdujemy także w Rozmowie Królów polskich Augusta III i St. Leszczyńskiego na Polach Elizejskich $1771 r^{54}$.

Przedstawione powyżej utwory są różnych rozmiarów i rangi. Część z nich, głównie wiersze, zawiera tylko opis określonych wydarzeń, w których uczestniczył Podoski i które zwrócily uwagę opinii publicznej, jest reakcją na nie (np.: Refleksje nad szubą...). Inne odnoszą się do prymasa w całości (np.: Sposób ratunku). Na uwagę zasługuje kilka tekstów pokaźniejszych, które, sądząc po ilości zachowanych odpisów, cieszyły się największą popularnością wśród czytelników. Są to dwa dramaty: Perekińczyk i Cnota uciemiężona, wolność obarczona oraz Rozmowa (...) Podoskiego (...) z (...) Przedwojewskim - zaprezentowana w tym tomie osobno.

W obu wspomnianych dramatach Podoski występuje jako jedna z postaci i, mimo że w Perekińczyku jest on tytułowym bohaterem, przedmiot

${ }^{51}$ Literatura barska, op. cit., s. 84, w. 13-18.

${ }^{52}$ Poezja barska, op. cit., s. 164-168.

${ }^{53}$ Literatura barska, op. cit., s. 315.

${ }^{54}$ M.in. zbiory akcesyjne 1983, s. 1-25, BOz 964 I, s. 1016. 
rozważań stanowi przede wszystkim intryga prowadząca do porwania senatorów. Pierwszy z nich inicjatorem wydarzenia czyni prymasa, drugi z wymienionych, obszerniejszy, pomysł całej intrygi przypisuje królowi i księciu kanclerzowi litewskiemu Michałowi Czartoryskiemu, natomiast inspiratorem porwania czyni również Podoskiego. Podoski przedstawiony jest jako człowiek zdolny do zdrady i każdej niegodziwości, byleby osiągnąć upragniony cel - purpurę. Z tym, że w Perekińczyku to on pociąga za sznurki, natomiast w Cnocie... sam jest jedną z marionetek, odpowiednio użytym narzędziem w rękach króla. Należałoby w tym miejscu zwrócić uwage na identyczność osób wystẹpujących w obu dramatach. A zatem wśród ich bohaterów odnajdujemy:

Perekińczyka - Podoskiego
Przemockiego - Repnina
Odstępskiego - Radziwiłla
Dobromyślskiego - Sołtyka
Szczerzeckiego - Rzewuskiego
Obrońskiego - jego syna, starostę dolińskiego
Żwaweckiego - Załuskiego, biskupa kijowskiego
Wykonalskiego - Igelstroma, oficera Przemockiego

Zauszniczkowskiego, pod którego imieniem w Perekińczyku kryje się Młodziejowski, a w Cnocie... - Wessel. Ponadto w Cnocie... występuje wiele dodatkowych postaci, których obecność uzasadnia odmienna koncepcja utworu. Należą do nich przede wszystkim Stanisław August - Despota i Michał Czartoryski - Wymyślicki. Występowanie ważniejszych $z$ nich $w$ obu tekstach sugeruje istnienie związku między nimi. W Cnocie... porwanie senatorów to skutek polityki Stanisława Augusta (nb. nie przewidziany przez niego), zmierzającej do ograniczenia wolności oraz swobód cywilnych i kościelnych. Podoski (Perekińczyk) użyty zostaje przez króla do przeprowadzenia tych zamierzeń. Wynikałoby zatem, że, oszukany jak wszyscy inni, detronizację Ciołka bierze za dobrą monetę. Ma być tylko narzędziem, nieświadomym przypisanej mu roli. W zamian za sukcesję po Łubieńskim (Staruszkiewiczu) zobowiązuje się przekonać wygnanego z kraju Radziwiłła (Odstępskiego), by przyjął laskę marszałkowską konfederacji w zamian za rehabilitację i przywrócenie skonfiskowanych dóbr. Należy jednakże podkreślić, że jeżeli autorstwo intrygi radomskiej przypisano królowi i Czartoryskiemu, to właśnie Perekińczyk radzi: „,...wziąć Dobromyślskiego, Żwaweckiego, Szczerzeckiego i Obrońskiego syna jego, to strach na wszystkich pójdzie...". Poza tym w imieniu Repnina namawia posłów do podpisania gwarancji, $w$ której między innymi konfederaci radomscy mają oświadczyć, że nie zawiązują się 
przeciw królowi. Jego charakterystyki dopełnia monolog ze sceny drugiej aktu trzeciego:

Gdy się znajduję w rozrywkach, nie czuję w sercu zgryzoty ani też w umyśle nieuspokojonych myśli. Skoro zaś na bezludności jestem, staje mi na myśli, żem i Wiarę, i Wolność narodu razem zgubić podjął się. Zdradzam przyjaciół, zdradzam Wiarę, zdradzam i Ojczyznę! Ach, co ja robię! Jakowy mam w sobie i na sobie charakter? Co ludzie i potomność sądzić o mnie będzie. Wyniesiony będe przez moc Przemockiego na najwyższy po Staruszkiewiczu stopień, atoli przez jakowy szczebel mam wstępować na niego? Trzeba mi wspaniałej rezolucyji, ukołysać serce, uśpić sumienie. Zamknąć oczy, bym na ludzi nie patrzył. Zatkać uszy, bym ich mów nie słyszał. Nadgrodzi mi wprawdzie dostojność tę podłość, którą mi przyznają, przyszła powaga teraźniejszy służebniczy umyst, obfite skarby zgryzotę sumienia, bo drożej Wiarę i Wolność przedaję niż Judasz sprawiedliwość. Wyniosę Familią, będę miał uwielbicielów różnych wiar. Choć bez mego kosztu, wystawią mi kolosy, będę miał i mauzolea. A nareszcie, co będzie potym, nie wiem. To wiem, że dobrze siedzieć $w$ tym krześle, w którym siedzieć będę... ${ }^{55}$

Perekińczyk obejmuje akcją krótszy okres niż Cnota... Zaczyna się w momencie, kiedy radomianie z Radziwiłlem i Sołtykim zaczęli orientować się, że zostali oszukani. Perekińczyk i Przemocki usiłują złamać opór Dobromyślskiego. W nadziei na jego poparcie, Perekińczyk nie może podjąć przeciw niemu żadnych radykalniejszych środków. Dlatego też tak jak w Cnocie udaje przyjaciela Dobromyślskiego. Natychmiast jednak po otrzymaniu pomyślnej wiadomości z Rzymu (chodzi oczywiście o zatwierdzenie prymasostwa przez papieża po wstawiennictwie Sołtyka), jego stosunek do tego ostatniego ulega zmianie. Radzi Przemockiemu: „Czegóż Waćpan czekasz? Dalej - daj ordynans, aby go w areszt wzięto."... Nie wdaje się przy tym w zbędne szczegóły, bowiem śpieszno mu na kolację $z$ panią Oemichen. Jego rada zostaje wprowadzona $w$ życie..., ale żolnierze pomylili się. Ofiarą pomyłki stał się sam... Perekińczyk, związano go i zbito zamiast biskupa krakowskiego. Projektu porwania nie zaniechano, postanowiono wprowadzić go $\mathrm{w}$ życie nazajutrz. Przygoda Perekińczyka (Podoskiego) to ostrzeżenie pod jego adresem zawarte $w$ umieszczonym na końcu utworu znanym przysłowiu: „Kto pod kim dołki kopie, sam w nie wpada."

${ }^{55}$ Tekst wg rękopisu ze zbiorów akcesyjnych BN 7068/2, s. 253. 
Twórcy literatury okolicznościowej stracili zainteresowanie postacią prymasa, gdy skompromitowany wyjechał do Elbląga, by połączyć się z panią Oemichen. W 1772 r. przenieśli się oboje do Gdańska, gdzie przebywali prawie pięć lat. W 1776 r. Podoski przekazał rządy archidiecezji w ręce księdza Ignacego Kozierowskiego i wyjechał z kraju. Jak głosi plotka, przedtem wziął potajemnie ślub z panią Oemichen, która nie chciała z nim zostać, dopóki nie udzieli im ślubu pastor ewangelicki. W tym samym roku przenieśli się do Marsylii, gdzie Podoski zmarł 3 kwietnia 1777 r. Niemal równocześnie zmarła pani Oemichen. Trumna ze zwłokami prymasa została złożona w kościele opactwa kanoników Saint-Victor de Marseille, gdzie leżała na podłodze do $1793 \mathrm{r}$. Wtedy to jego zabalsamowane szczątki zostały wrzucone do wód starego portu. 


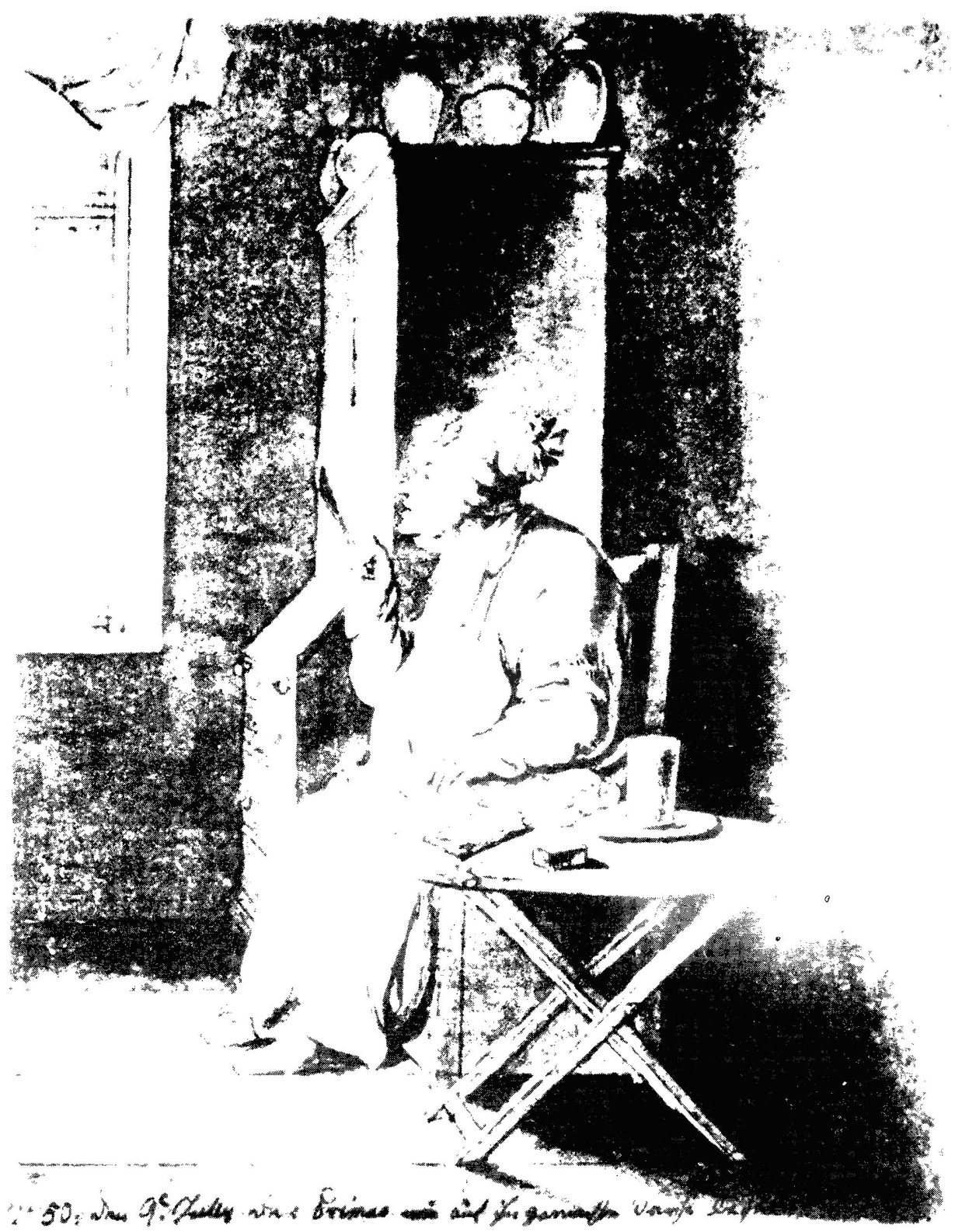

Rys. 5. Daniel Chodowiecki: Prymas Podoski w negliżu. 1773 


\title{
Rozmowa księcia prymasa Podoskiego z księdzem Przedwojewskim biskupem ekskapucynem 1769 Anno
}

\begin{abstract}
R
ozmowa księcia prymasa Podoskiego z ksiedzem Przedwojewskim..., jak większość utworów literatury barskiej jest anonimowa. Wprawdzie dosyć dokładna znajomość losów Podoskiego, oraz wzmianka w jednej z ostatnich wypowiedzi prymasa (jako osoby dialogu), wskazywałyby na autorstwo kogoś z jego środowiska, poszukiwania byłyby jednak czasochłonne i nie zapewniały powodzenia. Dlatego zrezygnowano z nich, znajdując usprawiedliwienie i w tym, że w literaturze barskiej, należącej do „folkloru szlacheckiego" - a więc kultury ",bezpersonalistycznej" - wiedza o indywidualnym twórcy utworu nie była istotna?.

Utwór, jak podaje tytuł, pochodzi z 1769 roku. Prawdopodobieństwo tej informacji potwierdza podana w tekście wzmianka dotycząca rozporządzenia wydanego przez Podoskiego, o usunięciu plebejuszy z seminarium łowickiego. Brak wiadomości o odwołaniu Repnina ze stanowiska ambasadora, w marcu 1769 roku, sugerowałby powstanie utworu w początkach tego roku. Oczywiście należy wziąć także pod uwagę możliwość późniejszego jego powstania. Autor mógł po prostu przemilczeć pewne wspólczesne wydarzenia, by z perspektywy czasu spojrzeć na postawę prymasa, jego udział i rolę $w$ konfederacji radomskiej. Postępowanie takie mogłaby uzasadniać chęć zdemaskowania intryg byłego referendarza, pokazanie ich następstw i ostrzeżenie przed nimi, a przede wszystkim ośmieszenie ewentualnego działania.

Dialog, wytwór ,folkloru szlacheckiego", obok zwrotów poważnych i podniosłych, zawiera wyrażenia dosadne, a czasem wulgarne. Wśród nich niepoślednią role pełnią zwroty frazeologiczne, nie zawsze dziś zrozumiałe, które niewątpliwie funkcjonowały w ówczesnym języku i były zrozumiałe
\end{abstract}

${ }^{1}$ Literatura barska, opr. Janusz Maciejewski. Bibl. Nar., S. I, nr 108, Wroclaw 1976, s. XCV, przyp. 9. 
dla czytelnika. Ośmieszają one niektóre postacie, ich postawy, sytuacje. Ważną rolę pelnią także aluzje do znanych powszechnie zachowań, np.: Podoskiego w czasie rekolekcji u ojców kapucynów w Warszawie lub Przedwojewskiego w Krakowie po powrocie z Rzymu. Można by tu mówić o tendencyjnym przedstawieniu postaci, na zasadzie kontrastu: dobry-zły ${ }^{2}$, zestawieniu faktów niewspółmiernych, a także elementach ironii, satyry, karykatury $w$ ich opisie oraz różnorodnej intensywności krytycyzmu w stosunku do nich. (Z tych względów utwór przypomina szopkę polityczną.) Wszystkie wymienione cechy składają się na swoisty komizm utworu, mierzący przede wszystkim w Podoskiego.

Rozmowę prowadzą dwie autentyczne postacie historyczne, Gabriel Podoski i Antoni Korneli Przedwojewski, występujące w utworze pod własnymi nazwiskami. Jest to fakt rzadko spotykany w literaturze okolicznościowej. Częściej bohaterowie okolicznościowej literatury politycznej są przedstawiani pod „mówiącymi imionami”, tak jest np.: w Perekińczyku, Cnocie uciemiężonej... lub stanowią postacie syntetyczne, np.: w Rozmowie saskiego kawalera z polskim senatorem. Nie znaczy to jednak, że omawiany tekst to wyjątek. Podobnie jest w Rozmowie J.W. Rzewuskiego, Wojewody Krakowskiego Hetmana Polnego Koronnego z synem swoim. Starosta Dolińskim, w niewoli moskiewskiej będących czy Rozmowie po śmierci Augusta I/l ze Stanisławem pierwszym Leszczyńskim. Przedwojewski i Podoski opowiadają o przebiegu swoich karier do roku 1769, ze szczególnym uwzględnieniem udziału $w$ konfederacji radomskiej. Obaj przyczynili się do zguby ludzi, którym powinni być wdzięczni za okazywane względy i pomoc, Wacława Rzewuskiego i Kajetana Sołtyka. Życiorys byłego kapucyna jest krótszy, zajmuje około jednej trzeciej utworu, a jego postać wydaje się pełnić rolę podrzędną względem postaci Podoskiego. Została przywołana jako punkt odniesienia, by ukazać ogrom winy arcybiskupa gnieźnieńskiego. Spośród wszystkich zarzutów stawianych temu ostatniemu najpoważniejszym i najbardziej akcentowanym jest zbrodnia przeciwko narodowi polskiemu - "gwarancja" rosyjska, o którą prosili radomianie i której autorstwo przypisywane jest Podoskiemu. Prymas opowiada, jak doszło do jej podpisania, nie kryjąc swego udziału w intrygach. Wydaje się nie rozumieć, na czym polega jego wina, skoro konstytucja ułożona w czasie obrad Delegacji jest „dokładna i dosyć rozumnie napisana". Podoski zdaje sobie sprawę, że nikt nie udzieli mu poparcia i boleje nad tym faktem. Tylko pozornie nie liczy się z opinią publiczną, bo gdy dochodzi do przeczytania "obojętnego" mu tekstu, przypadkiem znalezionego w kieszeni, pragnie poznać jego autora i ukarać go za zuchwalstwo. Został samotny, wzgardzony i opuszczony przez wszystkich. Gdyby doszukiwać się dydaktyzmu w Rozmowie..., tkwił-

\footnotetext{
${ }^{2}$ Rzewuski-Przedwojewski, Soltyk-Podoski. 
by on właśnie w przedstawieniu historii Prymasa, najbardziej znienawidzonego przez społeczeństwo i najbardziej nieszczęśliwego skutkiem własnego postępowania.

Tekst utworu zostal opracowany na podstawie czterech rękopisów, dwóch ze zbiorów Ossolińskich $(1479,566)$ oraz po jednym ze zbiorów Jagiellońskich (2794) i Czartoryskich (829). Za podstawowy uznano rękopis Ossolińskich 566, ze względu na jego najlepszą czytelność.

Ponadto odnotowano następujące przekazy

w zbiorach:

sygnatura

Biblioteki Archidiecezji Gnieźnieńskiej

Biblioteki Czartoryskich

234, s. 141

$830 \mathrm{IV}, \mathrm{s} .1$

Biblioteki Jagiellońskiej

865 IV, s. 122

5501, k. 191

6671, k. $47-52$

Biblioteki PAN w Krakowie

$316, k .83$ v

AGAD Sucha

$248 / 300$, k. 22 v

Biblioteki Polskiej w Paryżu

65 , s. $1901-1911$

Spośród wymienionych najbardziej wyróżnia się rękopis 829 ze zbiorów Czartoryskich. Różnice zauważalne są nie tylko w sferze językowej (wersja ta jest najbardziej dosadna i obfita $w$ wyrażenia nieparlamentarne), ale także w jego treści. Podane są tu fakty nie występujące w innych rękopisach, np. wzmianka o otruciu Łubieńskiego. Czasami połączone są $w$ jedną wypowiedzi dotyczące tego samego tematu. Poza tym często się zdarza, że zawarte $w$ nim wypowiedzi są obszerniejsze niż w innych rękopisach. $Z$ pozostałych przekazów wersje $w$ rękopisach ze zbiorów Bibliotek Ossolińskich 1479 i Jagiellońskiej 2794 są do siebie bardzo zbliżone. W obu, w przeciwieństwie do pozostałych dwóch, znajduje się informacja o kobietach, które pomogły Podoskiemu w realizacji intrygi. Rękopis ze zbiorów Ossolińskich 1479 wydaje się być skróconą wersją rękopisu ze zbiorów Jagiellońskich 2794. W wybranym rękopisie mamy do czynienia z wariantem pośrednim. Można $w$ nim znaleźć wersy zgodne bądź $z$ rękopisem ze zbiorów Czartoryskich 829, bądź z rękopisami ze zbiorów Ossolińskich 1479 i Jagiellońskich 2794.

W tekście utworu została zmodernizowana pisownia i interpunkcja, według zasad obowiązujących przy opracowywaniu tekstów staropolskich. Zachowano, nie zawsze konsekwentnie używany, czas zaprzeszły oraz dawne formy wyrazów. Pozostawiono także intencjonalne zmiany nazwisk, pani Oemichen, kochanki Podoskiego - Emkinowa, Hemkiniowa oraz Brühla, ministra Augusta III - Bruchl, Bruchel a jego żony - Bruch-, lowa $i$ in. 
W przypisach odnotowano wszystkie błędy znalezione w rękopisie podstawowym i zmiany wprowadzone w stosunku do niego. Oznaczenia: [...] lub [Pan Szasiler], ja[k], stosowane są w przypadku, gdy w rękopisie znajduje się wyraz nieczytelny, bądź jego znaczenia można domyślić się z kontekstu lub $\mathrm{w}$ porównaniu $\mathrm{z}$ innymi przekazami.

K.S. 


\section{Rozmowa księcia prymasa Podoskiego z księdzem Przedwojewskim biskupem ekskapucynem 1769 Anno' $^{1}$}

\section{PRYMAS}

Do diabła Mości Księżę z tym strojem francuskim, z tą fryzurą i peruką. Słyszałem, że Waszmość Pana potężnie ogadują. Przynajmniej z początku tej przemiany z kapucyna na biskupa trzeba było Waszmość Panu zachować jakąś przystojność i skromność $w$ odzieniu i długo się nosić tak jak inni biskupi. Lubo ja $\operatorname{sam}^{2}$ z biskupstwa i z sukien ich drwię.

\section{KAPUCYN}

Ja zaś wolę, żeby z początku na tę suknię, perukę $i$ obyczaje gadali. Nagadawszy się, to i przestaną ${ }^{3}$.

\section{PRYMAS}

W Rzymie napatrzyłem się, że zakonnicy, biskupi i kardynali zachowują kolor i znaki zakonu swego.

\section{KAPUCYN}

Daleko tu od Rzymu jesteśmy, możemy się stroić jak nam się tylko podoba. Mam obligacyją Waszej Książęcej Mości, żeś mię zrobił biskupem i mocno się cieszę, że woru mnichowskiego i wszy pozbyłem się.

1 Tytuł tekstu w pozostałych rękopisach brzmi: Rozmowa Jaśnie Oświeconego Księcia Jegomości Prymasa z Jegomością księdzem Przedwojewskim ekskapucynem (rkp. Jag. 2794), Rozmowa księdza prymasa Podoskiego z księdzem Przedwojewskim sufraganem ekskapucynem wkrótce po konsekracyji tegoż 1769 Anno (rkp. Czart. 829), Rozmowa księcia prymasa Podoskiego z księdzem Przedwojewskim ekskapucynem w samekarności do siebie opisana (rkp. Ossol. 1479).

${ }^{2}$ Zaimek ,sam" nie występował w rękopisie podstawowym, wprowadzono go za pozostałymi przekazami.

3 Forma imiesłowu występuje tylko $w$ rękopisie podstawowym, w pozostałych jest: "Nagadają się do woli i przestaną". 
PRYMAS

Świeccy księża, prałaci sarkają pokątnie na to, żem cię zrobił biskupem.

\section{KAPUCYN}

Pewnie, że im jest dużo markotno, a ja z tego drwię ${ }^{4}$.

\section{PRYMAS}

Ale nie ja pierwszy zrobiłem cię z mnicha biskupem. Jest ich takich kilku: koadiutor bakoński, sufragan wileński, kijowski, inflancki, ale wszyscy warci diabła.

\section{KAPUCYN}

To prawda, że Towiański nie wielka głowa ani Ossoliński, ani Olędzki, ani Sosnowski, wszystko to wielka prostota, przecież za mnie nie powstydzisz się Wasza Książęc a Mośćs.

\section{PRYMAS}

Jako widzę, Waszeć bardzo wielki galant, kapucyni sami ogadują Waszmość Pana.

\section{KAPUCYN}

Ci wszarze, to nierogate bydło, niekontenci są ze mnie?

\section{PRYMAS}

I pewnie powinni by sobie mieć za honor.

\section{KAPUCYN}

Pan Bóg Żydów z niewoli egipskiej, a ja kapucynów polskich z niewoli czeskiej wyprowadziłem. Czechowie za Boże stworzenie nie mieli Polaków. Ja pierwszy Polak byłem prowincjałem, concordata poczyniłem, wiem, co na to wydałem, wiem, jakiej w tym pracy zażyłem i com podejmował ${ }^{6}$.

\footnotetext{
${ }^{4}$ W rkp. Czart:
}

Kapucyn: Mając za co, musi im być markotno.

W pozostałych rękopisach również brak przymiotnika "dużo" oraz dalszego ciągu wypowiedzi.

${ }^{5} \mathrm{~W}$ rkp. Czart. są jeszcze następujące słowa: „,...bo i w glowie olej jest i w gębie dobrze, i co ludzie mogą, może i Przedwojewski sekretarz".

"W rkp. Ossol. ostatnie zdanie brzmi:C,Wiem, jakiej pracy podjąlem". 


\section{PRYMAS}

Cóż Waszmość Pan poradzisz, chcieliby, żebyśs Waszmość Pan i teraz był kapucynem.

\section{KAPUCYN}

Nie doczekają tego. Wolałbym czarta widzieć niż kapucyna. Wstyd mię nawet, kiedy gdzie obaczę obraz świętego Franciszka albo świętego Antoniego... Straszną mam abominacyją tego stroju, bo przedziwnie głupi jest ${ }^{7}$.

\section{PRYMAS}

Ale jednakowo mówią kapucyni, żeś nie przestał być kapucynem, ale żeś podobno nim nigdy nie był.

\section{KAPUCYN}

Bóg mię był skarał , a Wasza Książęca Mość uwolniłeś mię z tego więzienia.

\section{PRYMAS}

Powiadają, żeś Waszmość Pan, powracając z Rzymu, a będąc w Krakowie, w sukni kapucyńskiej, grywałeś Waszmość Pan w karty o pieniądze.

\section{KAPUCYN}

l cóż komu do tego $?^{9}$

\section{PRYMAS}

Ogadali Waszmość Pana ${ }^{10}$, że kapucyn w worze, z ogolonym łbem, z brodą jak honet bez pluder, z gołemi nogami, a czerwone złoto stawiłeś i sadziłeś na karty. Co widząc, zapewne śmieszna musiała być scena ${ }^{11}$. Kto widział, nie

\footnotetext{
${ }^{7} \mathrm{~W}$ rkp. Czart. ostatnie słowa kwestii brzmią: ,.....do tego stroju szalonego, bo też to jedynie straszydlo".

${ }^{8}$ W rkp. Czart. początek zdania jest obszerniejszy: ,To prawda, Bóg mnie był tym śmiesznym strojem skaral...".

${ }^{9}$ W rkp. Czart. wersja bogatsza o zdanie:

Kapucyn: Cóż komu do tego, bo byłem honet homo.

${ }^{10} \mathrm{~W}$ rkp. Czart. inny początek kwestii; pierwsze zdanie brzmi: "Na honor z tego drwią, że kapucyn w worze..."

${ }^{11} \mathrm{~W}$ pozostałych przekazach brak imiesłowowego równoważnika zdania rozpoczynającego kwestię, w rkp. Czart. ten fragment wypowiedzi brzmi: „Kto się na to patrzył, nie wierzył zapewne, że kapucynem byłeś..."
} 
wim $^{12}$ co sobie pomyślił, ale to wszystko jest kiepstwo ${ }^{13}$. To sęk $i$ treść, co - Waszmość Panu mówią i zapomnieć tego nie mogą, żeś swego dobrodzieja, Pana Hetmana Polnego Koronnego, Wojewodę Krakowskiego na sztych wydał ${ }^{14}$.

\section{KAPUCYN}

Wszakże radziłem mu, żeby tu był nie przyjeżdżał. Ja mu zawsze miałem i mam obligacyją ${ }^{15}$.

\section{PRYMAS}

Powiadają, że Hetmanowa kochała się w Waszmość Panu ${ }^{16}$.

\section{KAPUCYN}

Prawda, że była łaskawa na mnie i ona mi posłała drogę, abym kiedyś nie był kapucynem ${ }^{17}$. Uczyłem teologiji w Olesku przez pocztę! To jest siedziałem w Podhorcach, jadłem, piłem z oficyjerami bawiłem się. Teka dyktowała się w Olesku ${ }^{18}$.

\section{PRYMAS}

Jak uważam, to wygodnie być takim profesorem. Nowy to widzę sposób u mnichów zostania doktorem albo jubilatem ${ }^{19}$.

\footnotetext{
${ }^{12} \mathrm{~W}$ pozostalych rękopisach ,wiem".

${ }^{13} \mathrm{~W}$ pozostalych rękopisach brak rzeczownika , kiepstwo", a fragment wypowiedzi, w której występuje on w rękopisie podstawowym, w pozostałych przekazach brzmi: ,....ale to wszystko błazeństwo, to to sa blichty (rkp. Jag. - to zdanie kończy wypowiedź); ,.....ale to wszystko jeszcze blichty..." (rkp. Czart.).

${ }^{14} \mathrm{~W}$ żadnym z wymienionych we wstępie rękopisów nie ma zwrotu ,sęk i treść" występującego w rękopisie podstawowym; w rkp. Czart. ostatni fragment wypowiedzi brzmi: „Najwięcej o tym mówią, żeś Waszmość Pan zdradził swego osobliwego dobrodzieja i tegoś na sztych wydal, czego ludzie zapomnieć nie moga." w rkp, AGAD Sucha 248/300: ,....na sztych i z sekretu wydał..."

${ }^{15} \mathrm{~W}$ rkp. Czart. tekst Kapucyna jest znacznie obszerniejszy:

\section{Kapucyn:}

To też już nadto [znowu]. Ja mu miałem i mam wdzięczność. Prawda, żem się spodziewając in toto, nie in partibus biskupstwa, królowi, Familii, Repninowi powydawałem plany Hetmana Wojewody, ale też mu radziłem, żeby nie przyjeżdżał. On przecie wolał biskupa krakowskiego i wojewody kijowskiego sluchać. Przyjechał na swoje ciężkie licho i któż winien?

${ }^{16}$ W rkp. Ossol.:

Prymas: Powiadają, że na Waszmość Pana była Pani Hetmanowa laskawa.

${ }^{17}$ W rkp. Czart. ostatnie zdanie obszerniejsze: „ażebym przestał być obrzydliwym kapucynem”.

${ }^{18} \mathrm{~W}$ rkp. Czart. inny ostatni fragmient wypowiedzi Kapucyna: ,....To jest w ręku była teka, a ja siedziałem w Podhorcach, jadłem, piłem, grałem z oficyjerami, solennie bawiłem się."

${ }^{19} \mathrm{~W}$ rkp. Ossol. w kwestii Prymasa jeszcze jedno zdanie: „Ja rozumiem, że Waszmość Pan musiałeś być teologiem lub spowiednikiemin̈.
} 


\section{KAPUCYN}

A to wygodniejsza, bo się otworzę z sercem Waszej Książęcej Mości, że pod moim imieniem wyszły z druku kazania Pana Hetmana z pięknemi wierszami $^{20}$ na kształt prefacyji od niego ${ }^{21}$ napisanemi. Pan Hetman pod imieniem swoich synów zwykł był różne kompozycje swoje wydawać. Chwała Bogu, że mu nie przyszło do głowy uczynić syna którego kaznodzieją, na mnie więc obrócił oczy, gdy mnie się nie śniło na ten czas o kazaniach. Ale to najpiękniejsze, kiedy on sam lekcyje mi dawał w różnych naukach, kiedy mię napawał dobrym gustem, kiedy kazania za mnie pracowicie komponowal, jam się serdecznie na ten czas kochał ${ }^{22}$.

\section{PRYMAS}

$\mathrm{Ha}$, ha, ha, dobra i teologia, i katedra, czyli ambona do kazania.

\section{KAPUCYN}

Po całej nocy z nią przesiadywałem.

\section{PRYMAS}

A pan mąż pewnie nad kazaniem ślęczał ${ }^{23}$.

\section{KAPUCYN}

Urodziła była syna Pani Hetmanowa na lat kilka przed śmiercią. $O$, jakże mnie piekielnie tym dzieckiem prześladowano. Mówili, iż to jest istny Antoni (bo mię tak zwano u dworu) tylko mu bródki kapucyńskiej nie staje. Bóg dał,

${ }^{20} \mathrm{~W}$ rkp. Czart. pierwszy fragment wypowiedzi nieco odmienny:

Kapucyn: Ale to wygodniejsza (bo się nie mam racyji taić), owszem mam za powinność zwierzyć się z sekretu Waszej Książęcej Mości, że pod moim imieniem wychodzily z druku kazania Pana Hetmana i piękne wiersze...

${ }^{21}$ W rkp. Jag. i Czart.: „do niego".

${ }^{22} \mathrm{~W}$ rkp. Czart. ostatnie zdania wypowiedzi Kapucyna brzmią: ,....kiedy za mnie pracowicie kazania komponowal, ślęczal po nocach, jam się serdecznie w jego żonie kochał."; w rkp. Jag.: ,....jam się serdecznie w tej damie kochał".

${ }^{23} \mathrm{~W}$ rkp. Czart. ostatnie trzy kwestie brzmia następująco:

Prymas: Łepskiś Waść, ha, ha, to rzecz ładna.

Kapucyn: Umieliśmy się bawić i my też komponowali.

Prymas: $\mathrm{Ha}$, ha, ha, a Hetman biblię wertował za kapucyna.

w rkp. Jag. te same kwestie wyglądają następująco:

Prymas: $\mathrm{Ha}$, ha, ha.

Kapucyn: Do miłej nocy z nią siedziałem.

Prymas: Mąż jej nad kazaniem stękał. 
że ów chłopiec umarł, bo by go już dotąd kapucynem zwali. Prawda, ja naraziłem był sobie niektóre kobietki u dworu i dlatego tę bajkę rozsiano o mnie.

\section{PRYMAS}

To tedy, jak uważam, Pani Hetmanowa miała amantów?

\section{KAPUCYN}

Nigdy bez nich nie była. Oficyjerowie bywali za instancyją tej przyjmowani w regimentach, a potym w łańcuszkach siedzieli, a Włochów kastrastów odpędzono. Jam się tylko wypromował i miałem kredyt ${ }^{24}$.

\section{PRYMAS}

Bawi mię to mocno, co Waszmość powiedasz, a Hetmanże co na to?

\section{KAPUCYN}

Cierpiał jak dobry chrześcijanin. Pokrywał to jak mógł, kłócił się z nią, warty stawiał przed jej apartamentami. Pamiętasz Wasza Książęca Mość, że kiedy odjeżdżał do Drezna, to wszystko było z nieukontentowania.

\section{PRYMAS}

Ja rozumiem, że tam $w$ ten czas Waszmość Pan musiałeś być diabelnym teologiem i spowiednikiem.

\section{KAPUCYN}

Takim byłem jak Wasza Książęca Mość, kiedyś był u nas przed konsekracyją swoją na rekolekcyjach w klasztorze.

\section{PRYMAS}

Niechby czarci wzięli swoje rekolekcyje. Takiem po dwóch dniach mocno utęsknił, żem stamtąd uciekł do mojej Emchinowej. Umarłbym był, gdyby mi przyszło dłużej u Was siedzieć. Ja nie wiem, jak wy mnisi w klasztorach wytrzymacie.

\footnotetext{
${ }^{24}$ Pierwsze zdanie wypowiedzi. Kapucyna zarówno w rkp. Jag. jak i Czart. jest bez zmian. Dalej tekst brzmi: ,....Miala ich różnego gatunku; oficyjerów, bazylianów, kastratów. Oficyjerowie na pozór promowani byli w regimentach, a potem $w$ lańcuszkach siedzieli, Wlochów wypędzono, jam się przecie wypromował. Skończyła była na Szeptyckim Biskupie [płoc]kim..." (Tekst w rkp. wyraźnie skażony)t.
} 


\section{KAPUCYN}

Bóg mi też dał, żem się z niego wydobył. Niech biesi kapucynami będą, oszalałem, kiedym do nich wstąpił. Nieskończenie dziękuję Waszej Książęcej Mości, że tem mnichem i kapucynem więcej nie jestem.

\section{PRYMAS}

Ale mój kochany biskupie, powiedz mi rzetelnie, co o mnie ludzie i księża po Warszawie gadają.

\section{KAPUCYN}

Już nieraz powiadałem Waszej Książęcej Mości.

\section{PRYMAS}

Bo już mi te bzdury z głowy wyszły. Przypomnijże mi. Cóż tedy?

\section{KAPUCYN}

0 to, że Wasza Książęca Mość mszy nie miewasz, brewiarza nie znasz, podobno i zwyczajnego pacierza nie umiesz.

\section{KAPUCYN}

To bzdury. Jest więcej biskupów, co nigdy nie mawiają. Pewnie go mawia Kanclerz Wielki Koronny, warmiński lub inflancki biskupi? Pacierze niech mówią za mnie kapelani. Na to tych błaznów żywię, niech i msze odprawują, za cóż mają darmo chleb jeść. Ja nie wiem wiele mszy przez życie miałem i to z ostatniej potrzeby. Co pacierza nigdy nie mówię, bo to są głupstwa. Cóż więcej??

\footnotetext{
${ }^{25}$ W rkp. Czart. zamiast dialogu między Kapucynem a Prymasem, rozpoczynającego się od kwestii Prymasa „Ale mój kochany biskupie...", a kończącej również kwestią Prymasa „To bzdury. Jest więcej biskupów...", znajduje się tekst zwarty wypowiedziany przez Prymasa: "Wiem, żeś szczery. Powiedz mi rzetelnie, co tam o mnie mówią kapelani. Od tego tych blaznów chowam i żywię, niech i msze odprawują, za cóż mają darmo chleb jeść. Ja nie wiem, wiele też mszy przez życie z potrzeby ostatniej miałem [nie rozumiem czy] więcej nad dwa tuziny. Osobliwie pamiętam, że w Radomiu raniuteńko u Pijarów dobijałem się do klasztoru za mszę, podczas tej radomskiej konfederacyji, ale to dlatego, aby mnie przed szlachtą chwalili, żem skryty sluga boski, dobry ksiądz i zdam się na prymasa. Jakoż tym ich [odraiłem], choć niby mądrzy. Co pacierza nie mówię, bo też to jarzmo niepotrzebne i ostatnie glupstwo. Cóż więcej?".

Ponadto między tą a następną kwestią znajduje się następujący tekst:

Kapucyn: Już to mówiłem.

Prymas: Cóż?"
} 
KAPUCYN

Ale, ale, o tę Emchinową.

\section{PRYMAS}

Już by się powinni o nią uspokoić. Cóż więcej? ${ }^{26}$

\section{KAPUCYN}

O stół, że zawsze z mięsem i w piątki, i w Wigilie Wasza Książęca Mość jesz i wszystkim jeść dawać każesz.

\section{PRYMAS}

To są najmniejsze bagatele. Cóż więcej?

\section{KAPUCYN}

Żeś się Wasza Książęca Mość osadził dysydentami, że i komisarzów, ekonomów, pisarzów chowasz i trzymasz lutrów ${ }^{27}$.

\section{PRYMAS}

Wolno mi i radbym żadnego katolika przy sobie nie miećéc ${ }^{28}$. Cóż jeszcze?

\section{KAPUCYN}

Szemrają, żeś Wasza Książęca Mość rozpędziłeś Seminaryjum Łowickie, że księży $w$ archidiecezyji uczonych nie będzie.

\section{PRYMAS}

A małoż ich już sam Waszeć namazał, a do tego ja tylko samych chłopów z seminarium wypędziłem ${ }^{29}$.

${ }^{26}$ W rkp. Czart. wypowiedź Prymasa obszerniejsza:

Prymas: Oj, jużby się też powinno o niej uspokoić. Przed tym było co innego.

${ }^{27}$ W rkp. Czart. i Jag.:

Kapucyn: Także żeś Wasza książęca Mość osadzil [się] dysydentami. Marszałków, dworskich, konsyliarzów. [ekonomów] masz dysydentów.

W rkp. Ossol. ,... że i [konsylierzów], i ekonomów masz lutrów. mial."

${ }^{28}$ W rkp. Czart. wypowiedź bogatsza o slowo: "glupca": „jednego katolika, glupca nie

${ }^{29}$ W rkp. Czart. wypowiedź obszerniejsza:

Prymas: A cóż u diabła, a małożeś ich Waść w Łowiczu namazal? Jam tylko samych chłopów z seminarium wydał.

W rkp. Ossol. "wygnal” zamiast „wypędzil”. 
KAPUCYN

I ci by się zdali na pomniejsze beneficyja i wikaryje.

PRYMAS

Wszystko to fraszki. Cóż jeszcze mówią?

\section{KAPUCYN}

Żeś Wasza Książęca Mość chciał i usilował znosić zakonników, że ta konstytucyja, żeby do zakonu nie przyjmować tylko w dwudziestym czwartym roku jest Waszej Książęcej Mości jedyna robota i z jego projektu uczyniona.

\section{PRYMAS}

Prawda i to, ale cóż więcej?

\section{KAPUCYN}

Że Jezuitów i Pijarów świeccy ludzie utrzymali, kiedy Wasza Książęca Mość najbardziej upierałeś się, aby i ci, co się tycze przyjmowania do zakonu, pod tą konstytucją porównani byli ${ }^{30}$.

\section{PRYMAS}

Ja bym był i Jezuitów, i Pijarów, i wszystkich aniołów do wszystkich diabłów zniszczył, gdyby to w mojej mocy było. Jednakowoż im zawsze się dobrym pokazuję.

\section{KAPUCYN}

Gniewają się o to, że Wasza Książęca Mość chciałeś z Polski wyrzucić nuncjusza, a sam się chciałeś patriarchą uczynić.

\section{PRYMAS}

Niech będzie nuncjusz, ale bez nuncjatury. Niech by był tak, jak tu jest poseł pruski, duński, szwedzki, bez żadnej jurysdykcyji, bo ci Panowie Włoszkowie nadto się u nas rządzą. Jeden klecha ${ }^{31}$ ma mnie sądzić i rozstrząsać

\footnotetext{
${ }^{30}$ W rkp. Czart. wersja uboższa, jej ostatnie zdanie brzmi: „,... a Wasza Książęca Mość upieraleś się, żeby oni do tego prawa należeli."

${ }^{31} \mathrm{~W}$ rękopisie podstawowym niewątpliwy lapsus calami „,knechta" poprawiono za pozostałymi porównywanymi przekazami.
} 
sprawy moje i dekreta? Jak tylko zjadę do Łowicza, tak zaraz wszystkie dekreta nuncjaturskie pokasuję, które przez apelacyje pozachodziły i wszelkie apelacyje zachodzące poznoszę z mojej diecezyji. Wiem, że to będzie niestrawno nuncjuszowi i Rzymowi, ale ja się ich nie boję, zjedzą wszystkich diabłów. Cóż dalej? ${ }^{32}$

\section{KAPUCYN}

Na to najwięcej utyskują i o to są najbardziej źli na Waszą Książęcą Mość, żeś gwarancyją spraktykował na zgubę ojczyzny.

\section{PRYMAS}

Co? O tę gwarancyją? Czyż jeszcze o tym nie zapomnieli?

\section{KAPUCYN}

Oj, nie! Wszyscy jednostajnie ubolewają i wszyscy jednostajnym głosem i duchem wyznają, że Wasza Książęca Mość tego jesteś autorem.

\section{PRYMAS}

Nie taję się z niczym przed Waszmość Panem. Miałem zawsze godziwą ambicyją, zawsze chciałem się promować. Przypadłem był do humoru nieboszczykowi Bruchlowi. Dałby mi byl, nie wiem jakie biskupstwo, ale Królowa i Bruchlowa okrutnie temu sprzeciwiały się. Referendarstwo, order, probostwo miechowskie, dobrze, że to wziąłem. Widząc tedy, że mi do biskupstwa wszelkimi siłami przeszkadzała Królowa, rzuciłem się był do beneficjów. Miałem ich już z dziesięć, brałem jedno po drugim, które się tylko z królewskiej kolacyji nawinęło. Znowu biskupi świętaszkowie, (cl)amantes, jako to Sierakowski, Wężyk, Wołłowicz oponowali się i odsadzali mię od nich. A ja miałem swoje zasługi u dworu saskiego, a osobliwie u Bruchla. Byłem z negocjacyją w Gdańsku. To pewna, że mi się tam nie udało, bo te gbury grubiańsko sobie ze mną postąpiły na ten czas, ale potym dobrze tego przybeknęli, ponieważ im Bruchl pypcia zdarł. Jeździłèm potym do spiskiego starostwa, poczyniłem tam dyspozycje, z których Spiżanie nie byli kontenci. Biskup tamtejszy niekontent był ze mnie, żem tam chodził po francusku, w zielonych sukniach i z mięsem w posty jadałem.

\footnotetext{
${ }^{32}$ W rkp. Czart. końcowy fragment wypowiedzi Prymasa nieco obszerniejszy i odmienny: ,.... do Łowicza zjadę, dam ja sobie czas, wszystkie tam dekreta puszczę, a nuncjaturskie pokasuję, które w sprawach zaszly przez apelacyja mojej archidiecezyji. Wiem, że to będzie niestrawno nuncjuszowi i Rzymowi, ale zjedza wszystkich diabłów, nauczę ja ich [...] i mogę."
} 
KAPUCYN

Dlaczego to nienawidziała Waszą Książęcą Mość Królowa?

\section{PRYMAS}

Wolnom sobie mawiał o religii. Wymówiłem się był, że ja nie wierzę w Żywot Wieczny, że nikt nie wie tego, co nas po śmierci czeka, że wszelkie religie są to szaleństwo i bałamuctwo $i$ jedynie księże wymysły. A do tego z niektórymi Sasami, którzy nie bardzo się $w$ religii kochali, poufale żyłem i kareta moja prawie co dzień przez kilka godzin stawała przed Emchinową. Jakże tedy ja miałem się podobać Królowej? Prawda, że przekupowałem ja dworskich Jezuitów: Gwaryniego, Ligieryusza, Raucha, Hermana. Niemało na prezenta na nich wydałem. Dopiero jak się im nakłaniałem, coś się troszkę było odmieniło. Królowa jednak mawiała jeszcze, żem niezbożny, żem scandalosus.

\section{KAPUCYN}

A taż Emchinowa? $?^{33}$

\section{PRYMAS}

Jest to kobieta, którą ja kocham, wdzięczny jej jestem. Dawała mi pieniędzy, dawała wszystkiego. Nie miałbym jej, musiałbym mieć inszą. A kosztowałaby mnie insza więcej, bo to są dziury ${ }^{34}$ nie napchane, zaś do Emchinowej jużem się przyzwyczaił ${ }^{35}$. To pewna, że i za nię mię Królowa nie lubiła. Kiedy się zaś za przeszłego króla wypromować nie mogłem ani za teraźniejszych rządów żadnej do tego nie widziałem perspektywy i żadnym sposobem nie mogłem się spodziewać i otrzymać, umyśliłem i postanowiłem u siebie oddać się w protekcyją moskiewską, jakoż udało mi się dobrze.

\section{KAPUCYN}

Nie bardzo pono i dobrze, bo niedobre dla Ojczyzny wyniknęły skutki ${ }^{36}$.

\footnotetext{
${ }^{33} \mathrm{~W}$ innych rękopisach wypowiedź ta brzmi: w rkp. Czart:

Kapucyn: Ta Hemkinowa przeklęta wszystkiego okazyja.

w rkp. Jag.:

Kapucyn: Emkinowa co zacz?

${ }^{34}$ Słowo ,dziury" występuje tylko w rękopisie podstawowym - w pozostałych jest ",wory".

${ }^{35} \mathrm{~W}$ rkp. Czart. pierwsze zdania wypowiedzi brzmią: „Dajże jej pokój. Jest to kobieta poczciwa, którą ja kocham i wdzięczny jestem. Dawała mi pieniędzy. Nie miałbym jej, miałbym był inszą, darmo po ludzku żyć chciawszy. Kosziowałoby mnie to wiele, bo sa to wory nie napchane. A do tego do Hemkinowej jużem się przyzwyczaił."...

${ }^{36} \mathrm{~W}$ pozostałych rekkopisach kwestia ta brzmi:
} 


\section{PRYMAS}

Cóż robić, kiedy inaczej to być nie mogło. Ułożyliśmy plantę tej roboty z Repninem, komunikowaliśmy jej królowi. Ja potem wziąłem na siebie onejże egzekucyją. Pojechałem do Krakowa, najeździłem się po województwie. Starzy Wielopolscy nie chcieli wierzyć i tego się chwytać, jak o żelaznym wilku słuchali. Insi niełatwo się chwytali, niewypowiedziane miałem korowody i mozoły. A widząc $w$ tym trudność, uderzyłem w kobiety i powiodło mi się. Margrabina, Morsztynowa, Starościna Stobnicka dziwnie mnie sekundowały. Moje to apostołki były. Najprzód mężów swoich, a potym większą część województwa pozwodziły na moje słowa. Jak mi się ta maska udała, że król będzie detronizowany, gdyby muchy do miodu, co żywo do mnie Ignęli. Pewien z ministrów, także Wessel Podskarbi Wielki Koronny $i$ innych wielu mocno mi uwierzyli i wiązali się do mojej partyji. W tej opiniji porobiły się konfederacyje po województwach. Nastąpila potym konfederacyja radomska, której z mojej porady Moskwa asystowała, aby jakie przeciwne ułożeniom nie nastąpiły ustawy i artykuły. Sprowadziliśmy głupiego Radziwilła i dokazaliśmy wszystkiego. I musiałem tam nie chcący przysięgać dla utwierdzenia wątpliwych, i wiesz Waszmość Pan, że tam zaraz nominacyją na prymasostwo odebrałem. Natychmiast burza rzymska na mnie powstała. Znać, że we mnie cnót heroicznych do kanonizacyji nie widziano w Rzymie, a przyjaciele moi należycie mi się przysłużyli. I kiedy papież zostawał $w$ uporze, stanęła była rada nie dbać na fochy rzymskie. Miałem już wziąć purpurę i przysiąc na senatorską funkcyją, i zasięść jako prymas w Senacie, a dobra prymasowskie miały być oddane per commendam, do czego gorliwie się ofiarował biskup kujawski, jednakże inaczej rzeczy się obróciły. Jakiem się wziął kłaniać, biskupowi krakowskiemu podchlebiać, w ręce go całować, obiecywać, przyrzekać, nawiedzić jakie obowiązki zaprzysięgać siz̨, ułowiłem go. Uwierzył mi po tysiącznych przysięgach, na bilety mnie wyciągnął, atoli nic mi to nie szkodzi. Chociaż do niego pisałem i deklarowałem się z nim nieodstępnie trzymać, alem tego nie myślił dotrzymać. Tak mi zaś uwierzył, że i sam za mną do Rzymu napisał i kapitulę swoją do tego namówił. Do tego dał mi znaczne prezenta, począł się mną opiekować, począł mnie uczyć, co godzina kartki do mnie latały, osadził mnie był swojemi księżą. Pałacem Prymasowskim rządził się, już go reformował, rozwalał, budował etc. A co największa jest, że mi religią i miłość Ojczyzny gorąco i usilnie zalecał, a jam o czym innym myślił ${ }^{37}$.

Kapucyn: Co Waszmość Pan każesz? (rkp. Czart.)

Nie bardzo dobrze. (rkp. Jag.)

Niedobrze? (rkp. Ossol.)

${ }^{37}$ W rkp. Czart. wypowiedź Prymasa nie jest tekstem zwartym, został tu wprowadzony podział na role. Treść dialogu różni się także pod względem merytorycznym od treści wypowiedzi Prymasa z rękopisu podstawówego: 


\title{
KAPUCYN
}

\author{
Słyszałem, że Waszą Książęcą Mość posądzają o to wszystko, a najbardziej \\ o niewdzięczność ku temu biskupowi krakowskiemu.
}

Prymas: Kiedy inaczej być nie mogło, ułożyliśmy plantę tej roboty z Repninem, komunikowaliśmy jej królowi.

Kapucyn: I przecie udaio się.

Prymas: Udało się, ale oni na mnie, jak na osła, całą zwalili tak wielkiej sprawy egzekucyją, błysnąwszy mi tylko nadzieją prymasostwa, bo Łubieński już [zastabial] znacznie. Rad bym ja mu podal arszeniku dla uwolnienia od zgryzot tego życia. Ale sądzilem i pasłem się nadzieją, że i Młodziejowski to uczyni, bo i on tejże gratki, która mnie spotkać miała, spodziewał się.

Kapucyn: Bardzom ciekawy, jakeś te interesa kleił, Wasza Książęca Mość.

Prymas: Ho, ho, ho, siła by o tym mówić, ale tak w krótkości. Pojechałem do Krakowa, [nawłóczyłem] się jak Żyd po województwach, jużem rozpaczać począł. Wcale mi się z razu nie kojarzyło. Starzy Wielopolscy nie wierzyli, jak o żelaznym wilku słuchali. Inni wspominać sobie o tym nie dali albo [kondycyję] dyktowali, [zwoje] reskryptów wyciągali, dokumentów. Historyje nieskończone miałem. O nieszczęścież moje. Mówiłem, że przepadło prymasostwo, udałem się do [aktów] strzelistych, bo ja długich modlitw nie lubię. Narzuciłem na mnichów kilkanaście rublów, aby i oni beczeli. Jeśli ich krzykiem Bóg nie poruszy się, resztę potem żywą imaginacyją komponuję carowy projekt, że król będzie detronizowany i Familia pokarana za opresyją wolności. Sliczny koncept?

Kapucyn: Dalibóg, glowa nieoszacowana.

Prymas: Jak mi się ta inwencyja udala, że król detronizowany będzie, gdyby muchy do miodu co żywo do mnie Ignęły: wojewoda kijowski zakręcił wąsa, Mniszech na ten czas Marszałek Nadworny, Wessel Pisarz Wielki Koronny. Inni znowu przez nich egzorcyzmowani uwierzyli mojej relacyji, szalenie się rzucili do mojej partyji. Nastąpiła potem radomska konfederacyja, której Moskwa asystowała. Sprowadziliśmy potem glupiego Radziwilla. Dokazaliśmy wszystkiego. Musialem znowu przyrzekać, przysięgać, aby było utwierdzić wątpliwych. Już o tym musisz wiedzieć, żem tam odebrał nominacyją na prymasostwo. Odebratem, ale tu nie koniec.

Kapucyn: Cóż by znowu było?

Prymas: Burza na mnie rzymska... Znać, że w Rzymie nie wiedziano moich cnót do kanonizacyji, a przyjaciele moi należycie mi się przysłużyli. Kiedy więc papież przestawał w uporze, stanęla rada, aby nie dbać na fochy rzymskie. Miałem wziąć purpurę, przysiąc na senatorską funkcyję i zasiąść jako prymas w Senacie. Dobra zaś prymasowskie miały być oddane per comendam, ale i tu frantostwo było. Tylko jeszcze się ten nie urodzil, co by mnie w pole wywiódł. Zjedli diabła. Chcieli zakpić ze mnie.

Kapucyn: Jak to i w czym takim?

Prymas: Biskup kujawski [Pan Szasiler], arendarz, gorliwie się deklarował dobra wziąć w dyspozycyja i przystawić mi 400 [fm] przed sejmem zaraz. Ja[k] tylko zostałbym przy purpurze, pół psa pól kozy: arcybiskupstwo w Rzymie, dobra w ręku biskupa kijowskiego, u mnie tylko czerwony płotek. A nuż, gdyby się noga powinęla, abo jakby się znowu im ubrdało, pewnie by mnie i z tej czerwonej obdarli ferezyji i byl bym osech.

Kapucyn: Bardzo sprawiedliwa uwaga, slucham dalej.

Prymas: Jakiem się wziąl dopiero kłaniać biskupowi krakowskiemu, w ręce jego całować, obiecywać, zaprzysięgać się, ułowilem go. Uwierzył mi przecie po tysiącznych moich przysięgach, wyciągnął mnie na [bilety]. Cóż bylo czynić, musiałem malować cerografy 


\section{PRYMAS}

Ale nie wiem w czym? Chciał, żebym $z$ nim jedno trzymał i rozumiał na Sejmie, ale to być nie mogło, bo jużem był u siebie co innego postanowit. Zgubił się przez swój upór i pewnie, gdzie jest teraz, nigdy się stamtąd nie powróci. Polacy go żałują powszechnie, tak jak i Twojego Pana Hetmana. Mówią, że obydwa poczciwi ludzie, dobrzy katolicy, wierni Ojczyźnie senatorowie, a biskup krakowski, prawdziwy biskup. Ale niech tam sobie siedzą, gdzie przy naszej pomocy trafili, nam zaś tu dobrze bez nich. Wiedziałem ja wszystko w czasie, kiedy i jakim sposobem mieli być wzięci. Cieszyłem się, gdy byli porwani, nie tak z ich biedy, jako że bez nich latwo wszystko poszło na Sejmie, jakby z masłem. Wszyscy cicho siedzieli sobie, o naznaczoną delegacyją do traktowania z posłem rosyjskim już nie mówili i mówić nie śmieli ani się już przeciwnie nikt nie odezwał ${ }^{38}$.

i zakląłem się duszą i cialem, że z nim trzymać się, trzymać wiary będę, ale w myśli u mnie co innego było. [J]ak mi raz uwierzył biskup krakowski, że i sam za mną do Rzymu pisał, i kapitułę swoję do tego namówił. Dał mi znaczne procenta, począł się mną opiekować, co dzień kartki jego do mnie latały, osadzil mnie był swoimi [księżmi], Pałacem Prymasowskim rządzić się począł, już go rozwalał, rozprzestrzeniał, budowal, podnosil, oświecał, skrzydła wyciągał. A w nocy uprzykszeńsza rzecz była, nieustannie mi głowę klechtał religią święta i miłość Ojczyzny mi zalecając.

${ }^{38} \mathrm{~W}$ pozostalych rękopisach zamiast wypowiedzi Prymasa - dialog:

rkp. Czart.

Prymas: Nie wiem, w czym by chcial tego przez gwalt biskup krakowski, żebym z nim jedno trzymał w Sejmie. A możnaż to było? Ale żem ja co inszego jużem był u siebie postanowił. Zgubil się przez swój upór i pewnie gdzie jest, już nigdy stamtąd nie powróci. A mnie z tym dobrze, bo bym od wstydu samego zginąl.

Kapucyn: Polacy jednak go kochali, powszechnie wszyscy żałują go.

Prymas: Tak jak i Waścinego Wojewodę.

Kapucyn: Darmoć to inaczej mówić, tylko że obydwa poczciwi ludzie, dobrzy katolicy, wierni Ojczyźnie senatorowie, a biskup krakowski, prawdziwy biskup.

Prymas: To też ich trzeba bylo od nas hultajów odłączyć, niech tam sobie siedzą, gdzie trafili. A nam tu dobrze bez nich. Cieszyłem się poniekąd, kiedy byli porwani. Nie tak $z$ ich biedy, jako że bez nich latwo by wszystko poszło na sejmie, jakby z masłem i w samej rzeczy cudownie udawało się. Wszyscy jedno, jak pod berłem. Naznaczono delegacyja do traktowania z poslem rosyjskim, siedzieli wszyscy jak powarzeni.

w rkp. Ossol.

Prymas: Nie wiem w czym chcial, abym jedno z nim trzymał na Sejmie, ale to być nie mogło, bo jużem był u siebie co inszego postanowił. Zgubił się przez swój upór i gdzie jest, nigdy stamtąd nie powróci.

Kapucyn: Polacy go powszechnie żałują!

Prymas: Tak jak i Waszmość swojego Hetmana?

Kapucyn: Mówią, że obydwa poczciwi i wierni ojczyźnie senatorowie, ludzie dobrzy i katolicy wierni!

Prymas: Niech tam sobie siedzą, nam iu dobrze bez nich. Wiedziałem, kiedy i jakim sposobem mieli być wzięci. Cieszyłem się, jak ich porwano. Nie tak z ich bidy, jak że wszystko bez nich latwo poszło, wyszyscy cicho siedzieli. 


\section{KAPUCYN}

Wszyscy za rzecz pewną wierzą, że cokolwiek tam stanęło na tej niepraktykowanej delegacyji, toś Wasza Książęca Mość układał, pisał i poprawiat.

\section{PRYMAS}

A wszakże ta konstytucyja dosyć rozumnie jest napisana. Proszę mi pokazać, jakie innego sejmu ustawy, jeżeli są tak dokładne, jak ta konstytucyja.

\section{KAPUCYN}

O tęć to konstytucyją najbardziej źli są na Waszą Książęcą Mość wszyscy.

\section{PRYMAS}

A o cóż im chodzi?

\section{KAPUCYN}

Gwarancyja ich nieskończenie boli, a to co się w Polszcze dziś dzieje, tej gwarancyji skutkiem. Przyznam się, że to szkodzi znacznie Waszej Książęcej Mości.

\section{PRYMAS}

Ja o to nie dbam. Jednakowoż moglibyśmy i Moskwę oszukać. I tak Waść, Mości Księże biskupie, między ludźmi udawaj.

\section{KAPUCYN}

Ale jak oszukać? Czy to podobna...

\section{PRYMAS}

Gdybym tylko miał pomoc ${ }^{39}$.

\section{KAPUCYN}

Któż nam będzie wierzył? Poznali się na nas. 


\section{PRYMAS}

Prawda, że między biskupami nie masz kim trząsnąć. Kujawski i Kanclerz o skupowaniu dóbr, o pomnożeniu intrat myślą, płocki - zegarmistrz albo czerwone złote liczy i pakuje, inflancki cały $w$ amorach po uszy. $Z$ inszemi zaś, którzy po kątach i diecezyjach mieszkają, nie masz nic do czynienia. A minąwszy biskupów, między świeckimi panami nie mam nikogo, bom się nigdy o to nie starał, żebym sobie przyjaciół jednat. Szczególnie się o nieboszczyka Bruchla łaskę starałem, ten mój przyjaciel był, ten dobrodziej. Bracia moi nie zdatni i nie trzymają ze mną, bo Wojewoda Płocki nadto poczciwy, Podkomorzy szalony, a Kasztelan Rypiński do niczego. Widzisz tedy, Waszmość Pan, nie mam kogo zażyć.

\section{KAPUCYN}

Prawda, że wielkie to jest nieszczęście.

\section{PRYMAS}

Chciałbym żyć jak prymasom należy, jak inni antecessorowie moi żyli. Rad bym mieć i popularitatem, i kredyt. Dlatego i dwór wielki formowałem. Stół co dzień mam otwarty ${ }^{40}$.

\section{KAPUCYN}

Ale to jakoś Mości Książę nikt u nas z państwa, nikt z ludzi słusznych nie bywa, my tylko domowi, Moskal jaki czasem albo tacy ludzie, co obiadów po Warszawie szukają.

\section{PRYMAS}

Ktoś mi wczoraj do kieszeni, nie wiem jakim sposobem, wsunął te wierszyki, które chustkę wyjmując, wytrząsnąłem, a czytając, roześmiałem się. Czytaj no je Waszmość Pan ${ }^{41}$.

\footnotetext{
${ }^{40} \mathrm{~W}$ rkp. Czart. wersja obszerniejsza:

Prymas: Chciałbym, co większa już i kaptować, ale widzę, że ode mnie [nie wiedzieć] skąd mają odrazę. Chcialbym wspaniało, jako prymasowi należy, tak jak [antecysorowie] moi żyli. Rad bym mieć i popularitatem, i kredyt. Dlatego i dwór wielki formowalem. [Dom] codziennie mam otwarty, a nie cisną się do mnie.

${ }^{4} \mathrm{~W}$ rkp. Czart. wypowiedź nieco odmienna:

Prymas: Słuchaj no Waść, [ktoś] mi wczoraj do kieszeni wcisną te wierszyki. Czytając, roześmiałem się, bo ja tych plotek/nie zważan. Czytaj tylko Waszmość Pan.
} 
KAPUCYN czyta wiersze:

Chcesz wiedzieć, kto do stołu Prymasa zasiada

Kto do niego uczęszcza, kto z nim pije, jada

Prymas Byk w środku, obok baba Emchinowa

$Z$ drugiej strony Rypińska olenderska krowa

Tu kasztelan rypiński, a tu z kapucyna

Jakby zapustowego widzieć Arlekina

To $w$ peruce, to $w$ włosach swych ufryzowany

Z sukni nie ksiądz, nie biskup, cóż to za przemiany

Dopiero mnich, już z niego człowiek cale świecki

Stój, umysł $i$ charakter widziec ${ }^{42} w$ nim zdradziecki

$Z$ Antoniego drwią wszyscy, a on baje ${ }^{43}$ baśnie

Włoch źrze, pije, jako ${ }^{44}$ wieprz bzdzi, a często trzaśnie

Obaczysz tam jakiego Moskala lub Sasa

$\mathrm{Ci}$ to są stołownicy Polskiego ${ }^{45}$ Prymasa

\section{PRYMAS}

Będzie to kompozycyjka którego z moich panów pokojowych. Gdybym się mógł dowiedzieć, który to napisał ${ }^{46}$ ?

\section{KAPUCYN}

To paszkwil jest. Rękę za to uciąć.

\section{PRYMAS}

Kazałbym mu ze trzysta kańczugów dać, ale ja się z tego śmieję. Dziwno mi jednak, że nas tak dobrze znają, że portrety nasze tak doskonale odmalowane $\mathrm{e}^{47}$.

\footnotetext{
${ }^{42}$ W rkp. Ossol. zamiast „,widzieć", ,[w]cale”; w rkp. Czart. ,,jako".

${ }^{43}$ W rkp. Czart. ,prawi" zamiast "baje".

${ }^{44} \mathrm{~W}$ rękopisie podstawowym ,jak" poprawiono zgodnie z rytmem na ,jako" za rkp. Czart.

${ }^{45} \mathrm{~W}$ pozostałych rękopisach brak zaimka „to", zamiast „Polskiego" jest ,zwyczajni”.

${ }^{46}$ W rkp. Czart. i Jag. wersja nieco obszerniejsza:

Prymas: Będzie to kompozycyjka któregoś z panów pokojowców. Gdybym się mógl dowiedzieć, który to napisał, poczęstować bym kazał jegomości. (rkp. Czart.)

Prymas: Będzie to kompozycyjka którego z pokojowych. A ja się z tego śmieję. Gdybym się mógl dowiedzieć, który to napisał? (rkp. Jag.)

${ }^{47} \mathrm{~W}$ rkp. Czart. wypowiedź obszerniejsza:

Prymas: Co mi po jego ręce. Kazałbym dać trzysta kańczugów w dupę, aż by się zeszczał, ale się i z tego śmieję. Dziwno mi tylko, że nas tak dobrze znają, iż portrety nasze doskonale malować umieja.
} 


\section{KAPUCYN}

Wierz mi Wasza Książęca Mość, że ludzie domowi wszystko wynoszą o Waszej Książęcej Mości. Onegdaj się mnie pytano, czyli to prawda, że książę co dzień z rana, kurząc tytuń, na stołku ${ }^{48}$ po dwie godziny siada? Czy prawda, że krucice nabite w kieszeniach u pluder zawsze nosi? Czy prawda, że się nigdy nie modli i nie spowiada? Etc.

\section{PRYMAS}

Idź Waść do diabła z tymi bajkami etc.

Opracowala KATARZYNA SAŁKIEWICZ

${ }^{48} \mathrm{~W}$ rkp. podstawowym prawdopodobnie lapsus calami "stoku” zostal poprawiony na podstawie pozostałych porównywanych rékopisów. 